\title{
ROLE OF CARBONIC ANHYDRASE IN THE BICARBO- NATE EXCRETION FROM SALIVARY GLANDS AND MECHANISM OF IONIC EXCRETION
}

\author{
HISATO YOSHIMURA, HAYATA IWASAKI, TATSUO NISHIKAWA \\ AND SATOSHI MATSUMOTO* \\ Department of Physiology, Kyoto Prefectural University of Medicine, Kyoto
}

In the previous report from the authors' laboratory (1), it was concluded that the main factor governing the $p H$ of saliva is its bicarbonate concentration, and a suggestion was made that the bicarbonate of saliva is produced from the metabolic $\mathrm{CO}_{2}$ in gland cells, because the salivary bicarbonate concentration runs parallel with the rate of salivary flow, i.e. the activity of gland cells, and sometimes surpasses the level of serum bicarbonate when the salivary flow is copious. The first aim of the present investigation is to ascertain the above mentioned suggestion by examining the rôle of carbonic anhydrase in the bicarbonate production of salivary gland.

With regard to this problem, Sand (2) verified with the use of radioactive tracer, $\mathrm{C}^{14}$, that the bicarbonate of saliva originates at least partly from the metabolic $\mathrm{CO}_{2}$ of gland cells. In another experiment (3), he demonstrated the presence of carbonic anhydrase (designated as C.A.) in the salivary glands and suggested that this enzyme catalyzes the following hydration reaction of metabolic $\mathrm{CO}_{2}$,

$$
\mathrm{CO}_{2}+\mathrm{H}_{2} \mathrm{O} \stackrel{\text { C.A. }}{\rightleftarrows} \mathrm{H}_{2} \mathrm{CO}_{3} \rightleftarrows \mathrm{H}^{+}+\mathrm{HCO}_{3}{ }^{-},
$$

and the bicarbonate formation is accerelated by dissociation of the hydrated product.

Van Goor (4) determined also the carbonic anhydrase content of the three large salivary glands of dog, i.e. parotid, submaxillary and sublingual gland, and found that the parotid gland contains the highest amount, while the sublingual gland does the least. From this result, he suggested the presence of the carbonic anhydrase in serous cells in the salivary gland, and its possible rôle in the bicarbonate production of the salivary glands. These suggestions on the rôle of carbonic anhydrase in the productions of salivary bicarbonate require, however, further experimental verifications.

The rôle of carbonic anhydrase in the $\mathrm{HCl}$ excretion from gastric gland was long discussed, since Davenport (5) reported its presence in the border

Received for publication September 1, 1958.

* 吉村寿人, 岩崎隼太, 西川辰夫, 松本 敏

This paper is dedicated to Dr. Rinnosuke Shoji, professor emeritus of Kyoto University, for the celebration of his 70 th birth day. 
cells of gastric mucosa. Recently Hollander (6) verified its important rôle in acid production by demonstrating that the acid production is inhibited by a potent carbonic anhydrase inhibitor, Diamox. But none has ever reported the effects on salivary bicarbonate excretion. Thus its verification should be the first step to approach the problem.

At the second step, the authors planned to compare the bicarbonate excretion from various glands and their carbonic anhydrase contents. If the carbonic anhydrase plays an important rôle in the physiological excretion of the bicarbonate in saliva, the bicarbonate excretion from various glands should differ according to the amount of carbonic anhydrase in these glands.

To explain the mechanism of bicarbonate excretion, a general consideration upon the excretory mechanism of ions from salivary gland is required. According to the classical hypothesis of Merkel (cited from Babkin (7)), water and salts in saliva are excreted from different parts of ducts and are mixed with viscous excretion of organic substance from alveolar cells. This hypothesis was subjected to critics by many authors and is not believed to be completely correct. Recently Thaysen, Thorn and Schwartz (8) introduced a new concept in the mechanism of salivary excretion. According to them, parotid saliva is made hypotonic by reabsorption of $\mathrm{NaCl}$ by some process of limited capacity from the precursor solution produced in the gland. White et al. (9) compared tonicities of excreta from various glands with their histological structures and concluded that the parotid, as well as the submaxillary saliva, is made hypotonic by a reabsorptive function of rodded epithelium in the excretory duct.

In this investigation, excretions of main salts in saliva from various glands were measured in connection with the observation of bicarbonate excretion. From these data, the authors attempted to criticize the previous hypothesis of ionic excretions, and to discuss the excretory mechanism with special reference to that of bicarbonate. This is the final aim of the present investigation.

\section{EXPERIMENTAL METHODS}

Experiments were carried out in two series. One concerns the effects of carbonic anhydrase inhibitors upon the excretion of bicarbonate in saliva, and the other is to compare the bicarbonate excretion and the carbonic anhydrase content of various sorts of salivary glands. In this measurement, other important inorganic components such as $\mathrm{Na}, \mathrm{K}, \mathrm{Cl}$ were also measured, and their excretion rates were compared among the glands. The animals used were mainly adult dogs, and the salivary sample was usually collected after the subcutaneous pilocarpine injection. The followings are the details of experimental methods.

a) Experiments on effects of carbonic anhydrase inhibitors upon the bicarbonate excretion of salivary glands of dog

The carbonic anhydrase inhibitors examined in the present experiment are 2-acetylamino-1, 3, 4-thiadiazole-5-sulfonamide (Diamox), thiophen-2-sulfonamide, sulfanilamide, $p$-sulfonamide benzoic acid, $\mathrm{NaSCN}, \mathrm{Na}_{2} \mathrm{~S}$, and $\mathrm{NaN}_{2}$. The first 
5 belong to specific inhibitors, while the last two are non specific. As Diamox sample was sent from American Cynamid Co. after the experiments were completed with the other inhibitors, it was experimented only supplementally.

The experiments were done in two stages. First, the effects of inhibitors upon blood carbonic anhydrase of dogs were examined in vitro, and then effects of these inhibitors on the bicarbonate excretion in saliva were studied in vivo with the same experimental animals after administration of inhibitors.

In the experiment of blood carbonic anhydrase, $1 \mathrm{ml}$. blood sample which was diluted to 20 fold with the physiological $\mathrm{NaCl}$ solution was introduced in the sampling flask of Warburg's manometer, and the activity of the carbonic anhydrase of the blood sample was firstly estimated according to Altschule and Lewis (10), by measuring the velocity constant of $\mathrm{CO}_{2}$ liberation reaction from the bicarbonate solution $(\mathrm{N} / 40)$ which was mixed with the diluted blood sample ( $1 \mathrm{ml}$.) in a Warburg's flask. As the velocity constant is increased under influence of carbonic anhydrase, its increase from the control value without carbonic anhydrase can represent the activity of the enzyme. Thus the activity of blood carbonic anhydrase, $E$, was expressed by the increase of velocity constant which was converted into that of $1 \mathrm{ml}$. undiluted blood sample by the proportional calculation from the experimental value of diluted sample (10).

In order to examine the effect of an inhibitor, its certain amount was dissolved in physiological $\mathrm{NaCl}$ solution, and the solution was used to dilute the blood sample. With this sample, $\mathrm{CO}_{2}$ liberation velocity was measured as above and the activity of blood carbonic anhydrase, $E^{\prime}$, was calculated. The inhibitory effect of the inhibitor examined, $I$, was calculated by the following equation,

$$
I=100 \times\left(E-E^{\prime}\right) / E(\%) .
$$

In the in vivo experiments, three dogs $(9-12 \mathrm{~kg})$ with permanent parotid fistula were used without anesthesia and the excretion of parotid saliva was initiated by pilocarpine injection $(0.05 \mathrm{ml}$. of $1 \%$ solution $/ \mathrm{kg})$. In the control experiment, which was repeated three times with one and the same dog, salivary samples were collected successively until 60 minutes after pilocarpine injection, and the $p \mathrm{H}$ and the total $\mathrm{CO}_{2}$ content were determined in relation with the rate of salivary flow. On days other than those on which the control experiment was carried on, the dog was injected intravenously with a carbonic anhydrase inhibitor, and immediately thereafter, the pilocarpine was injected subcutaneously. The collections of salivary samples and their measurements were carried out with the same manner as in the control experiment. The amount of inhibitor injected was weighed so as to be contained in the blood approximately in the same concentration as in the blood sample of in vitro experiment under the postulation of no loss outside the blood vessels. It was ascertained by a preliminary experiment that this amount can exert its maximum action upon the salivary bicarbonate excretion without showing any poisonous effects.

b) Comparisons of the salts excretion from various salivary glands and their carbonic anhydrase contents

Dogs were anesthetized with Cyclopan (sodium n-methyl-cyclohexenyl- 
methyl-barbiturate), and the ducts of parotid, submaxillary and sublingual glands were cannulated with fine glass or polyethylene tubes. One \% pilocarpine solution $(0.05 \mathrm{ml} / \mathrm{kg}$.) was injected subcutaneously and the successive collections of saliva followed it with 10 or 15 minutes intervals simultaneously but separately from various glands. As the sublingual gland can excrete only very little saliva, the collection was made with 30 or 60 minutes interval.

After the collection of saliva for 60 or 90 minutes, the carotid artery was cut and the dog was shed. One $\% \mathrm{NaCl}$ solution warmed at $38^{\circ} \mathrm{C}$ was transfused from the jugular vein and the blood was washed out completely until the colour of sheding fluid from the artery almost disappeared. The dog died already at this time, and the salivary glands were excised promptly. The glands were washed again with $1 \% \mathrm{NaCl}$ solution to take off blood and each of them was homogenized with a homogenizer kept at $0^{\circ} \mathrm{C}$. The homogenates of the glands were diluted to 20 fold with $1 \% \mathrm{NaCl}$ solution, and with these diluted samples, the carbonic anhydrase contents of the glands were determined by Altschule and Lewis' method (10).

Six dogs were experimented and the carbonic anhydrase activity of salivary gland was measured with four of them. Four rabbits were also experimented to compare their parotid gland activity with the dogs'.

\section{c) Measurements of saliva samples}

The saliva was colleceted under the liquid paraffin in a small graduated test tube from the cannule which was inserted to the fistula or the duct of the gland. The volume of the sample was measured each 10 or 15 minutes and the rate of salivary flow per minute was calculated.

The $p_{\mathrm{H}}$ of the saliva was measured by the micro-glass electrode deviced by one of the authors (11), and its total $\mathrm{CO}_{2}$ content was analysed by Saito's micro-blood gas analyser (12) which is a modification of Van Slyke's manometric apparatus. The reagents for gas analysis of saliva were those perscribed by Matsuda (13). The $\mathrm{CO}_{2}$ partial pressure, $\mathrm{PcO}_{2}$, of the saliva was calculated from Bunsen coefficient of free $\mathrm{CO}_{2}$ and its content in saliva, $\left[\mathrm{CO}_{2}\right]$, which was derived from the following Henderson-Hasselbalch's equation,

$$
p \mathrm{H}=p K^{\prime}+\log \frac{\left[\mathrm{HCO}_{3}^{-}\right]}{\left[\mathrm{CO}_{2}\right\rfloor},
$$

where $p K^{\prime}$ is the dissociation exponent of the carbonic acid, and is reported to be 6.22 at $37^{\circ} \mathrm{C}$. in saliva by Matsuda et al. (13). $\mathrm{Na}$ and $\mathrm{K}$ of saliva were determined with Lange's flame photometer (15), and $\mathrm{Cl}$ with Schales and Schales method (16).

\section{EXPERIMENTAL RESULTS AND DISCUSSIONS}

\section{Effects of carbonic anhydrase inhibitors}

\section{A. In vitro experiments with blood}

The carbonic anhydrase inhibitors being added to blood of three dogs, their effects upon liberation velocity of $\mathrm{CO}_{2}$ from the bicarbonate solution were 
TABLE 1. Comparison of Effects of Various Inhibitors Upon Carbonic Anhydrase in Dog Bood (In Vitro Experiment)

\begin{tabular}{|c|c|c|c|c|c|c|c|c|c|}
\hline \multirow{3}{*}{$\begin{array}{c}\text { C.A. } \\
\text { Inhibitors }\end{array}$} & \multirow{3}{*}{$\begin{array}{l}\text { Mol conc. } \\
\text { in blood }\end{array}$} & \multirow{3}{*}{ Dog } & \multicolumn{4}{|c|}{$\begin{array}{l}\text { Activity of C.A. } \\
\text { (per m. per ml.) }\end{array}$} & \multirow{2}{*}{\multicolumn{2}{|c|}{$\begin{array}{c}\text { Percentage } \\
\text { inhibition }(I) \\
(\%)\end{array}$}} & \multirow{3}{*}{\begin{tabular}{|c} 
In- \\
hibitory \\
effect \\
per \\
$1 \times 10^{-3}$ \\
$\mathbf{M}(\%)$ \\
\end{tabular}} \\
\hline & & & \multicolumn{2}{|c|}{ Control $(E)$} & \multicolumn{2}{|c|}{$\begin{array}{c}\text { After inhibitor } \\
\left(E^{\prime}\right)\end{array}$} & & & \\
\hline & & & $\begin{array}{c}\text { Ob- } \\
\text { served }\end{array}$ & Mean & $\begin{array}{c}\text { Ob- } \\
\text { served }\end{array}$ & Mean & $\begin{array}{c}\text { Ob- } \\
\text { served }\end{array}$ & Mean & \\
\hline $\begin{array}{l}\text { Thiophen-2- } \\
\text { sulfonamide }\end{array}$ & $0.7 \times 10^{-3}$ & $\begin{array}{l}\mathrm{A} \\
\mathrm{B} \\
\mathrm{C}\end{array}$ & $\begin{array}{l}0.990 \\
0.952 \\
0.983\end{array}$ & 0.975 & $\begin{array}{l}0.241 \\
0.131 \\
0.156\end{array}$ & 0.176 & $\begin{array}{l}75.5 \\
86.2 \\
84.1\end{array}$ & 82.0 & 116.0 \\
\hline $\mathrm{Na}_{2} \mathrm{~S}$ & $3.5 \times 10^{-3}$ & $\begin{array}{l}\mathrm{A} \\
\mathrm{B} \\
\mathrm{C}\end{array}$ & $\begin{array}{l}0.990 \\
0.952 \\
0.983\end{array}$ & 0.975 & $\begin{array}{l}0.350 \\
0.297 \\
0.302\end{array}$ & 0.316 & $\begin{array}{l}64.6 \\
68.8 \\
69.3\end{array}$ & 67.6 & 19.3 \\
\hline $\mathrm{NaN}_{3}$ & $5.2 \times 10^{-3}$ & $\begin{array}{l}\mathrm{A} \\
\mathrm{B} \\
\mathrm{C}\end{array}$ & $\begin{array}{l}0.990 \\
0.952 \\
0.983\end{array}$ & 0.975 & $\begin{array}{l}0.459 \\
0.553 \\
0.444\end{array}$ & 0.485 & $\begin{array}{l}53.6 \\
41.9 \\
54.8\end{array}$ & 50.1 & 9.7 \\
\hline $\begin{array}{l}\text { Sul- } \\
\text { fanilamide }\end{array}$ & $7.8 \times 10^{-3}$ & $\begin{array}{l}\text { A } \\
\text { B } \\
\text { C }\end{array}$ & $\begin{array}{l}0.990 \\
0.952 \\
0.983\end{array}$ & 0.975 & $\begin{array}{l}0.388 \\
0.364 \\
0.276\end{array}$ & 0.343 & $\begin{array}{l}60.8 \\
61.8 \\
71.9\end{array}$ & 64.8 & 8.3 \\
\hline $\begin{array}{c}p \text {-Sul- } \\
\text { fonamide } \\
\text { benzoic } \\
\text { acid }\end{array}$ & $7.1 \times 10^{-3}$ & $\begin{array}{l}\mathrm{A} \\
\mathrm{B} \\
\mathrm{C}\end{array}$ & $\begin{array}{l}0.990 \\
0.952 \\
0.983\end{array}$ & 0.975 & $\begin{array}{l}0.590 \\
0.614 \\
0.563\end{array}$ & 0.589 & $\begin{array}{l}40.4 \\
35.5 \\
42.7\end{array}$ & 39.5 & 5.6 \\
\hline $\mathrm{NaSCN}$ & $9.0 \times 10^{-3}$ & $\begin{array}{l}\mathrm{A} \\
\mathrm{B} \\
\mathrm{C}\end{array}$ & $\begin{array}{l}0.990 \\
0.952 \\
0.983\end{array}$ & 0.975 & $\begin{array}{l}0.908 \\
0.913 \\
0.944\end{array}$ & 0.922 & $\begin{array}{l}8.3 \\
4.1 \\
4.0\end{array}$ & 5.5 & 0.6 \\
\hline $\begin{array}{l}\text { Acetazole- } \\
\text { amide } \\
\text { (Diamox) }\end{array}$ & $0.7 \times 10^{-3}$ & $\begin{array}{l}\mathrm{A}^{\prime} \\
\mathrm{B}^{\prime} \\
\mathrm{C}^{\prime}\end{array}$ & $\begin{array}{l}1.031 \\
0.816 \\
0.863\end{array}$ & 0.903 & $\begin{array}{l}0.039 \\
0.007 \\
0.007\end{array}$ & 0.018 & $\begin{array}{l}96.0 \\
99.0 \\
99.0\end{array}$ & 98.0 & 140.0 \\
\hline
\end{tabular}

examined in vitro. The results are illustrated in table 1 . The mean carbonic anhydrase activity of $1 \mathrm{ml}$. undiluted control blood is 0.975 among dogs $A, B$ and $C$, while it is 0.903 among $A^{\prime}, B^{\prime}$ and $C^{\prime}$. By adding inhibitors to the samples, $\mathrm{CO}_{2}$ liberation velocity decreases, and the inhibitory effect, $I$, varies from $5.5 \%$ to $98.0 \%$ of the control value. In the experiments, the concentrations of inhibitors are different from one another. Therefore, in order to compare the inhibitory effects more accurately among inhibitors, they should be converted into the value for one and the same concentration. Assuming that inhibitory action is proportional to the amount of inhibitor contained in the blood, the effects of inhibitors per $1 \times 10^{-3} \mathrm{M}$ are calculated in the right end column of the table. As the value may surpass $100 \%$ inhibition by this calculation, it loses the physical meaning, and should be utilized only for comparison of relative inhibitory action. It is clearly demonstrated in the table that Diamox is the most potent inhibitor, thiophen-2-sulfonamide the next and the others are weaker among which NaSCN is the weakest. The strong effect of Diamox was already pointed out by Berliner et al. (14) and that of thiophen-2-sulfonamide by Davenport (5). The above order of magnitude of inhibitery action of various agents is useful to compare with their effects upon alkali excretion of salivary glands. 
B. In vivo experiments of effects of inhibitors upon the alkali excretion from salivary gland.

Prior to the experiments, the dogs were operated to prepare the permanent fistula of parotid gland, and the control experiments of salivary excretion without carbonic anhydrase inhibitor were carried out with these dogs. The saliva was collected with 10 minutes intervals after pilocarpine injection and was analysed. The results are shown in fig. 1, where the data of $\operatorname{dog} B$ are illustrated as an example. The confidence range of control saliva of each successive collection is calculated and the dotted band is figured by connecting them with each other. As is seen in the figure, the rate of salivary flow and total $\mathrm{CO}_{2}$ contents after carbonic anhydrase inhibitors are situated in the control range, while $p_{\mathrm{H}}$ and $\mathrm{PcO}_{2}$ of saliva after potent inhibitors such as thiophen2 -sulfonamide, $\mathrm{Na}_{2} \mathrm{~S}, \mathrm{NaN}_{3}$, sulfanilamide are commonly located outside. Thus carbonic anhydrase inhibitors may influence upon salivary gland to excrete less alkaline (lower $p_{\mathrm{H}}$ ) saliva and to increase its $\mathrm{CO}_{2}$ partial pressure.

Data of all saliva collections for 60 minutes after pilocarpine being averaged on each animal, the mean values with their standard deviations are presented in table 2. The difference between the control values and the values after carbonic anhydrase inhibitor are subjected to Student's test and the significant values are indicated with asterisks, i.e. * at 5\% level and ** at $1 \%$ level. It is clearely demonstrated in the table that the data which are the most markedly effected by inhibitors are $p \mathrm{H}$ and $\mathrm{PcO}_{2}$, while the rate of salivary flow are not influenced at all. The total $\mathrm{CO}_{2}$ content may sometimes be influenced but not consistently.
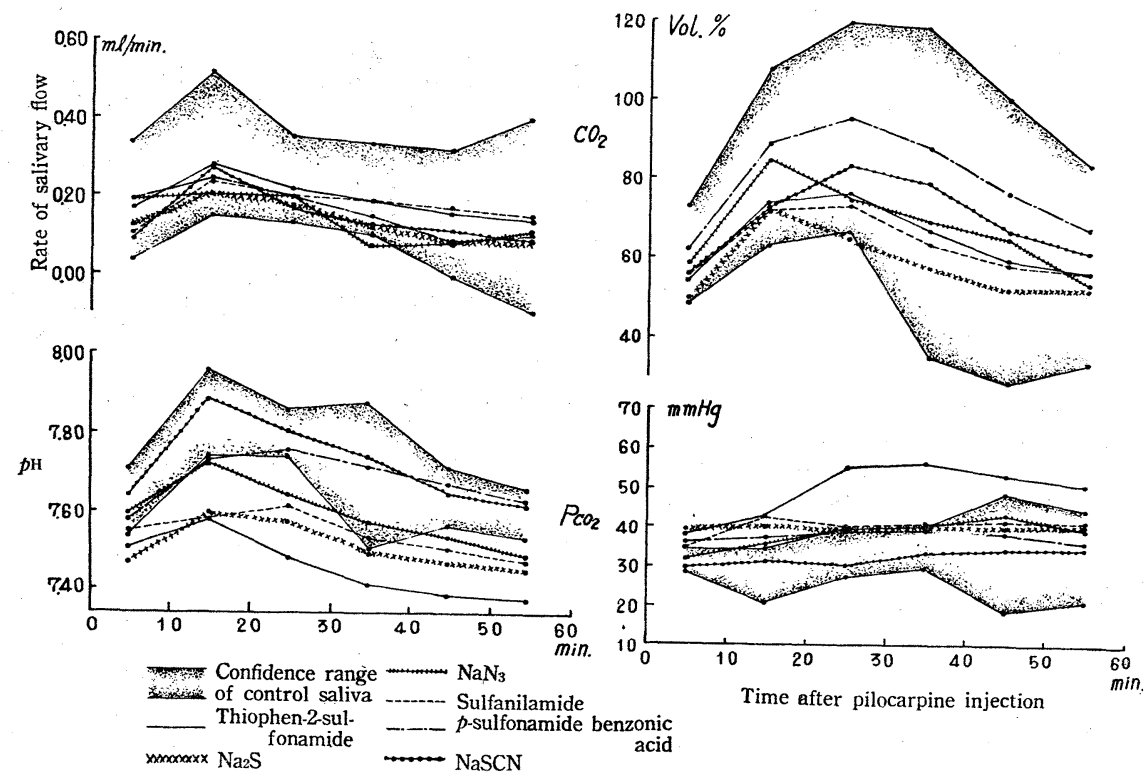

FIG. 1. Rate of salivary flow and acid base balance of parotid saliva after pilocarpine injection (Dog B). 
TABLE 2. Effects of Carbonic Anhydrase Inhibitors upon Acid-Base Balance of Parotid Saliva of Dog (Values after \pm are standard deviations)

\begin{tabular}{|c|c|c|c|c|c|c|}
\hline 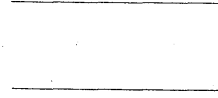 & $\begin{array}{l}\text { Infused } \\
\text { amount } \\
(\mathrm{M} / \mathrm{kg})\end{array}$ & Dog & $\mid \begin{array}{c}\text { Rate of } \\
\text { salivary flow } \\
(\mathrm{ml} / \mathrm{min})\end{array}$ & $p \mathrm{H}$ & $\begin{array}{c}\mathrm{CO}_{2} \\
(\mathrm{Vol} \%)\end{array}$ & $\underset{(\mathrm{mmHg})}{\mathrm{Pco}_{2}}$ \\
\hline Control & & $\begin{array}{l}\mathrm{A} \\
\mathrm{B} \\
\mathrm{C}\end{array}$ & $\begin{array}{l}0.35 \pm 0.18 \\
0.20 \pm 0.27 \\
0.28 \pm 0.10\end{array}$ & $\begin{array}{l}7.883 \pm 0.111 \\
7.694 \pm 0.032 \\
7.815 \pm 0.074\end{array}$ & $\begin{array}{r}116 \pm 24 \\
72 \pm 16 \\
124 \pm 20\end{array}$ & $\begin{array}{l}34.4 \pm 7.0 \\
32.4 \pm 3.7 \\
43.0 \pm 8.2\end{array}$ \\
\hline $\begin{array}{l}\text { Thiophen-2- } \\
\text { sulfonamide }\end{array}$ & $0.54 \times 10^{-4}$ & $\begin{array}{l}\mathrm{A} \\
\mathrm{B} \\
\mathrm{C}\end{array}$ & $\begin{array}{l}0.45 \pm 0.19 \\
0.19 \pm 0.05 \\
0.38 \pm 0.13\end{array}$ & $\begin{array}{l}* * 7.729 \pm 0.089 \\
* * 7.455 \pm 0.072 \\
* * 7.591 \pm 0.056\end{array}$ & $\begin{array}{r}119 \pm 13 \\
64 \pm 8 \\
112 \pm 11\end{array}$ & $\begin{array}{c}* * 50.3 \pm 5.5 \\
* * 49.3 \pm 6.7 \\
* * 63.7 \pm 2.8 \\
(48.8 \%)\end{array}$ \\
\hline $\mathrm{Na}_{2} \mathrm{~S}$ & $2.7 \times 10^{-4}$ & $\begin{array}{l}\mathrm{A} \\
\mathrm{B} \\
\mathrm{C}\end{array}$ & $\begin{array}{l}0.32 \pm 0.14 \\
0.13 \pm 0.05 \\
0.30 \pm 0.11\end{array}$ & $\begin{array}{l}* * 7.643 \pm 0.063 \\
* * 7.505 \pm 0.060 \\
* * 7.590 \pm 0.052\end{array}$ & $\begin{array}{l}* * 93 \pm 18 \\
* 58 \pm 7 \\
* * 104 \pm 13\end{array}$ & $\begin{array}{c}* * 46.7 \pm 6.5 \\
* * 39.7 \pm 4.8 \\
* * 59.0 \pm 2.9 \\
(31.8 \%)\end{array}$ \\
\hline $\mathrm{NaN}_{3}$ & $4.0 \times 10^{-4}$ & $\begin{array}{l}\mathrm{A} \\
\mathrm{B} \\
\mathrm{C}\end{array}$ & $\begin{array}{l}0.41 \pm 0.12 \\
0.14 \pm 0.06 \\
0.14 \pm 0.02\end{array}$ & $\begin{array}{l}* * 7.625 \pm 0.079 \\
* * 7.588 \pm 0.074 \\
* * 7.619 \pm 0.055\end{array}$ & $\begin{array}{r}* * 91 \pm 16 \\
67 \pm 10 \\
* 105 \pm 11\end{array}$ & $\begin{array}{c}* * 48.7 \pm 4.3 \\
* * 38.2 \pm 3.3 \\
* * 56.2 \pm 3.0 \\
(30.1 \%)\end{array}$ \\
\hline Sulfanilamide & $6.0 \times 10^{-4}$ & $\begin{array}{l}A \\
B \\
C\end{array}$ & $\begin{array}{l}0.40 \pm 0.29 \\
0.17 \pm 0.04 \\
0.29 \pm 0.12\end{array}$ & $\begin{array}{r}* 7.678 \pm 0.119 \\
* * 7.538 \pm 0.044 \\
* * 7.642 \pm 0.078\end{array}$ & $\begin{array}{r}107 \pm 31 \\
62 \pm 6 \\
115 \pm 8\end{array}$ & $\begin{array}{c}* 40.3 \pm 2.2 \\
* * 39.9 \pm 2.3 \\
* * 59.3 \pm 8.9 \\
(26.0 \%)\end{array}$ \\
\hline $\begin{array}{l}p \text {-Sulfonamide } \\
\text { benzoic acid }\end{array}$ & $5.45 \times 10^{-4}$ & $\begin{array}{l}\mathrm{A} \\
\mathrm{B} \\
\mathrm{C}\end{array}$ & $\begin{array}{l}0.41 \pm 0.21 \\
0.16 \pm 0.06 \\
0.29 \pm 0.09\end{array}$ & $\begin{array}{r}7.857 \pm 0.075 \\
7.676 \pm 0.060 \\
* * 7.692 \pm 0.067\end{array}$ & $\begin{array}{r}129 \pm 15 \\
79 \pm 12 \\
114 \pm 14\end{array}$ & $\begin{array}{c}* 40.5 \pm 2.1 \\
* * 36.9 \pm 0.9 \\
* * 51.7 \pm 4.9 \\
(17.3 \%)\end{array}$ \\
\hline $\mathrm{NaSCN}$ & $6.9 \times 10^{-4}$ & $\begin{array}{l}\mathrm{A} \\
\mathrm{B} \\
\mathrm{C}\end{array}$ & $\begin{array}{l}0.43 \pm 0.23 \\
0.14 \pm 0.06 \\
0.26 \pm 0.05\end{array}$ & $\begin{array}{l}7.875 \pm 0.046 \\
7.705 \pm 0.082 \\
7.787 \pm 0.071\end{array}$ & $\begin{array}{r}134 \pm 14 \\
69 \pm 3 \\
126 \pm 17\end{array}$ & $\begin{array}{c}* 40.6 \pm 3.8 \\
31.9 \pm 2.0 \\
* * 46.7 \pm 8.3 \\
(8.4 \%)\end{array}$ \\
\hline \multirow{2}{*}{ Diamox } & Control & $\begin{array}{l}\mathrm{A}^{\prime} \\
\mathrm{B}^{\prime}\end{array}$ & $\begin{array}{l}0.31 \pm 0.20 \\
0.33 \pm 0.18\end{array}$ & $\begin{array}{l}7.840 \pm 0.022 \\
8.165 \pm 0.018\end{array}$ & $\begin{array}{r}78 \pm 14 \\
130 \pm 17\end{array}$ & $\begin{array}{l}23.9 \pm 3.4 \\
20.3 \pm 2.2\end{array}$ \\
\hline & $0.31 \times 10^{-4}$ & $\begin{array}{l}\mathrm{A}^{\prime} \\
\mathrm{B}^{\prime}\end{array}$ & $\begin{array}{l}0.27 \pm 0.21 \\
0.28 \pm 0.16\end{array}$ & $\begin{array}{r}7.829 \pm 0.161 \\
* * 7.929 \pm 0.120\end{array}$ & $\begin{array}{r}* 109 \pm 29 \\
131 \pm 28\end{array}$ & $\begin{array}{c}* * 34.6 \pm 4.5 \\
* * 34.1 \pm 2.8 \\
(61.4 \%)\end{array}$ \\
\hline
\end{tabular}

* means that the difference from the control value is statistically significant at $5 \%$ level, while the value with $* *$ is significant at $1 \%$ level.

The value in parenthesis is the mean value of percentage rises of $\mathrm{Pco}_{2}$ in saliva from their respective controls.

In order to compare the inhibitory actions of agents examined, with one another, the mean percentage rises of $\mathrm{CO}_{2}$ partial pressure of saliva relative to the control value were calculated, and were converted to the values for one and the same dosage $\left(0.77 \times 10^{-4} \mathrm{M}\right.$ per $\mathrm{kg}$. body weight $)$ by aid of proportional calculation. Results are plotted in fig. 2 in relation with the inhibitory effects of the agents for $\mathrm{CO}_{2}$ liberation velocity which were estimated by the in vitro experiment. The points lie beautifully on a straight line which passes the zero point. Thus inhibitory actions of in vivo experiments run parallel to those of in vitro experiments. 


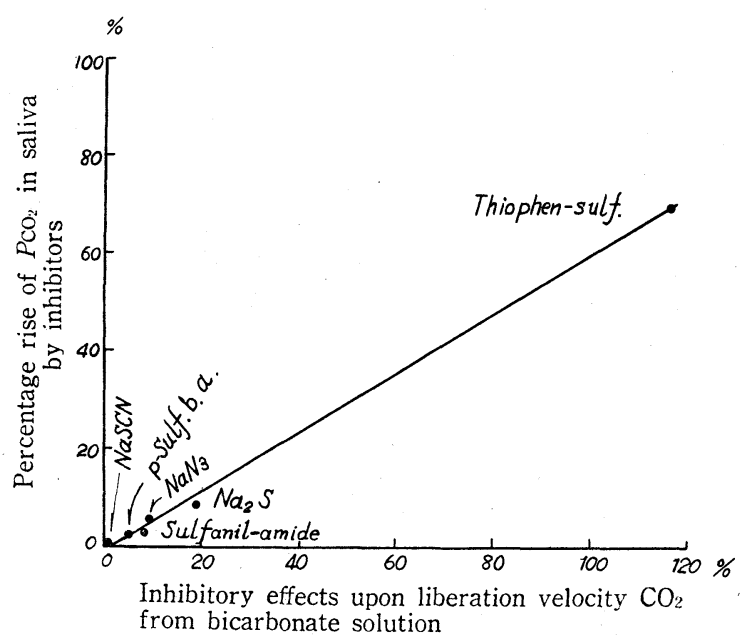

FIG. 2. Comparison of effects of carbonic anhydrase inhibitors of in vitro and in vivo experiments.

Effects of Diamox upon salivary constituents were similar to the above experiments. As the experimental animals are different in the case of Diamox, the data were not plotted in Fig. 2. The calculation of the percentage rise of $\mathrm{PCO}_{2}$ after Diamox was, however, made from data in table 2, and was converted to the amount described as above. It is $141 \%$ on the average and is comparable to the effect found in the in vitro experiment.

In conclusion, it is verified experimentally that, when the carbonic anhydrase inhibitor is administered to dog, the $\mathrm{CO}_{2}$ partial pressure in saliva is rasied and its $p_{\mathrm{H}}$ is decreased in direct proportion to its inhibitory action upon the enzyme.

\section{Comparisons of the salts excretion from various salivary glands}

Results of ionic measurements of six dogs after pilocarpine injection are summarized in fig. 3 , where the ionic concentrations of various saliva are plotted against the rate of salivary flow. It is shown in the figure that $\mathrm{Na}^{+}, \mathrm{Cl}^{-}$and total $\mathrm{CO}_{2}$ concentrations and $p_{\mathrm{H}}$ in saliva increase in parallel with the rate of salivary flow in case of submaxillary and parotid saliva and each of them reaches the maximum plateau at a certain high level of flowing rate. On the other hand, $\mathrm{K}^{+}$concentration drops to a certain level in both saliva and is maintained constant even as the salivary flow increases. The facts coincide well with the previous authors $(1,8,17)$.

In case of sublingual saliva, $\mathrm{Na}^{+}, \mathrm{Cl}^{-}, \mathrm{K}^{+}$, total $\mathrm{CO}_{2}$ concentrations and $\mathrm{pH}$ do not seem to vary appreciably with the flowing rate.

The ionic compositions of three sorts of saliva which were collected for 1 hour after pilocarpine are illustrated in table 3 . As the tonicity of saliva is maintained mainly by $\mathrm{Na}^{+}, \mathrm{K}^{+}, \mathrm{Cl}^{-}$and bicarbonate concentrations, the total sum of these ionic concentrations may roughly represent the level of tonicity. It is demonstrated in the table that parotid as well as submaxillary saliva are hypotonic, while sublingual saliva is approximately isotonic. As the salts con- 

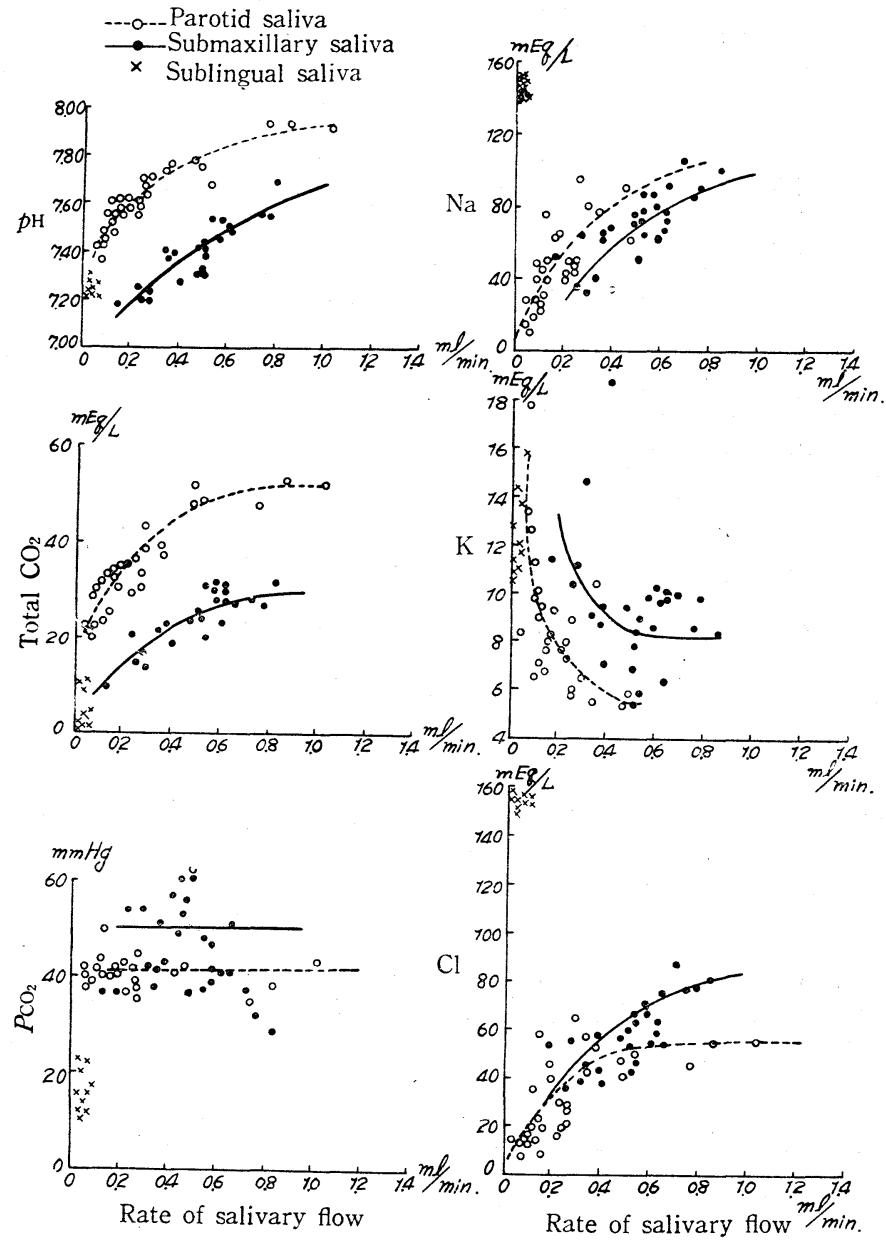

FIG. 3. Compositions of saliva in relation with rate of salivary flow (dogs).

centrations of parotid as well as submaxillary saliva are increased by the accerelation of flowing rate, they tend to approach near isotonic level though still remaining somewhat hypotonic at the maximum.

$\mathrm{Na}^{+}$and $\mathrm{K}^{+}$concentrations of parotid saliva are approximately the same with those in submaxillary saliva respectively at one and the same flowing rate, while the anion concentration differs considerably between the two. Thus, the chloride concentration is lower and bicarbonate is higher in parotid than in submaxillary saliva (see fig. 3 ). As the $\mathrm{CO}_{2}$ partial pressure is the same between the two, the $p_{\mathrm{H}}$ of parotid saliva is higher than that of submaxillary sample at every rate of flowing. In sublingual saliva, the total $\mathrm{CO}_{2}$ content as well as the $p_{\mathrm{H}}$ is far low as compared with the other two saliva, while $\mathrm{Na}^{+}$ and $\mathrm{Cl}^{-}$are in the highest concentrations (see table 3).

To clarify why the ionic compositions are different among the three sorts 
TABLE 3. Ionic Composition and Excretory Rate of Saliva Collected from Parotid, Submaxillary and Sublingual Gland for 1 Hour after Pilocarpine Injection

\begin{tabular}{|c|c|c|c|c|c|c|}
\hline \multicolumn{3}{|c|}{ Animal } & \multicolumn{3}{|c|}{ Dogs } & \multirow{2}{*}{$\frac{\text { Rabbits }}{\text { Parotid gl. }}$} \\
\hline & Gland & & Parotid gl. & Submax. g & gl. Subling. gl. & \\
\hline \multicolumn{3}{|c|}{ Nos. of experiments } & 4 & 4 & 4 & 4 \\
\hline \multicolumn{3}{|c|}{ Mean weights ( $\mathrm{gm}$ ) } & 4.3 & 3.6 & 1.1 & 1.5 \\
\hline \multicolumn{3}{|c|}{ Saliva volume $(\mathrm{ml})$} & 8.7 & 30.9 & 1.2 & 7.2 \\
\hline 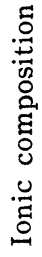 & $\begin{array}{l}\mathrm{Na}^{+} \\
\mathrm{K}^{+} \\
\mathrm{Cl}^{-} \\
\mathrm{HCO}_{3}^{-} \\
\text {Total } \mathrm{CO}_{2} \\
\mathrm{pH} \\
\text { Total cations } \\
\text { Total anions } \\
\text { Total sum of ion }\end{array}$ & $\begin{array}{c}\mathrm{mEq} / \mathrm{L}) \\
\prime \prime \\
\prime \prime \\
\prime \prime \\
\prime \prime \\
\prime \prime \\
\prime \prime \\
\quad \prime\end{array}$ & $\begin{array}{c}45.9 \\
8.0 \\
26.5 \\
29.8 \\
32.0 \\
7.62 \\
53.9 \\
55.3 \\
109.2\end{array}$ & $\begin{array}{c}74.7 \\
8.9 \\
61.8 \\
24.9 \\
27.1 \\
7.42 \\
83.6 \\
86.9 \\
170.5\end{array}$ & $\begin{array}{c}145.1 \\
12.0 \\
154.1 \\
5.2 \\
5.8 \\
7.21 \\
157.1 \\
159.3 \\
316.4\end{array}$ & $\begin{array}{c}106.6 \\
7.3 \\
106.0 \\
8.1 \\
9.0 \\
7.16 \\
113.9 \\
114.1 \\
228.0\end{array}$ \\
\hline
\end{tabular}

of saliva, the carbonic anhydrase contents and also histological structures of these glands were investigated. Moreover, the measurements of salivary compositions of rabbit parotid gland was supplemented. Summarizing these experimental results together with those described above, the following discussions will be made.

\section{The carbonic anhydrase content in salivary glands and the bicarbonate} excretion

The carbonic anhydrase content in three sorts of salivary glands were measured by Althule and Lewis' method with four dogs out of the six in the above experiment. The results are presented in table 4, where $E$ is the increase of velocity constant of $\mathrm{CO}_{2}$ liberation from the bicarbonate solution $(\mathrm{N} / 40)$ by addition of $1 \mathrm{gm}$. undiluted homogenate of tissue, and thus represents the carbonic anhydrase activity of gland. As $N$ in the table is its nitrogen content in

TABLE 4. Contents of Carbonic Anhydrase in Salivary Glands of Dogs and Rabbits

\begin{tabular}{c|c|c|c|c|c|c}
\hline \hline Animal & Organ & $\begin{array}{c}\text { Nos. of } \\
\text { samples }\end{array}$ & $\begin{array}{c}\text { Weight } \\
(\mathbf{g m})\end{array}$ & $E / \mathrm{gm}$ & $N(\mathrm{mg}) / \mathrm{gm}$ & $E / N$ \\
\hline \hline \multirow{3}{*}{ Dogs } & Parotid. gl & 4 & 4.31 & $0.762 \pm 0.018$ & 12.4 & $0.061 \pm 0.004$ \\
& Submax. gl & 4 & 3.63 & $0.216 \pm 0.017$ & 10.0 & $0.022 \pm 0.004$ \\
& Subling. gl & 4 & 1.06 & $0.029 \pm 0.004$ & 14.8 & $0.002 \pm 0.001$ \\
\hline \multirow{2}{*}{ Rabbits } & Parotid. gl & 4 & 1.49 & $0.043 \pm 0.007$ & 3.7 & $0.012 \pm 0.002$ \\
\hline
\end{tabular}

$E$ represents the carbonic anhydrase content in $1 \mathrm{mg}$. tissue in term of an increase of the velocity constant of $\mathrm{CO}_{2}$ liberation from bicarbonate solution. $N$ is the nitrogen content per $1 \mathrm{~g}$. tissue, and $E / N$ is the carbonic anhydrase per $\mathrm{g}$. nitrogen. 
$1 \mathrm{~g}$. tissue, $E / N$ is the carbonic anhydrase activity per mg. nitrogen in gland tissue. It is clearly demonstrated in the table that the carbonic anhydrase activity is the highest in parotid and the lowest in sublingual gland. The middle is in submaxillary gland. This order of carbonic anhydrase activity is the same with that of the bicarbonate contents in saliva from the three sorts of glands which are shown in table 3. The ionic composition of rabbit parotid saliva is supplemented in the last column of the table as well as in Fig. 5. The methods of measurements were similar to those of dog. It is shown that the bicarbonate concentration of rabbit parotid saliva is middle between those of sublingual and submaxillary saliva. This order coincides with that of carbonic anhydrase contents in the three glands as is demonstrated in table 4.

Summarizing the fact together with the observation on effects of carbonic anhydrase inhibitors stated above, it is concluded that the carbonic anhydrase in salivary gland plays an important rôle in the excretion of bicarbonate. The possible rôle of carbonic anhydrase (C.A.) is an acceleration of the following hydration reaction of metabolic $\mathrm{CO}_{2}$ in gland cells.

$$
\mathrm{CO}_{2}+\mathrm{H}_{2} \mathrm{O} \stackrel{\text { C.A. }}{\rightleftarrows} \mathrm{H}_{2} \mathrm{CO}_{3} \rightleftarrows \mathrm{H}^{+}+\mathrm{HCO}_{3}^{-}
$$

$\mathrm{HCO}_{3}-$ ion here formed seems to equilibrate with $\mathrm{Na}^{+}$from $\mathrm{NaCl}$ in tissue fluid by some ion exchange mechanism through the cell membrane and thus the sodium bicarbonate may be produced as follows (refer to Yoshimura et al. (1)):

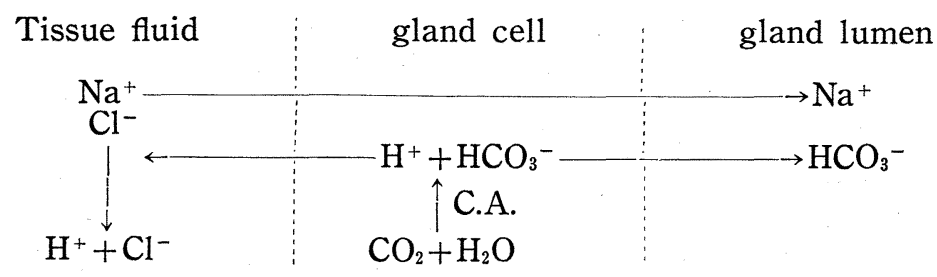

From this hypothesis, $\mathrm{HCl}$ should be liberated in tissue fluid, when salivary excretion is increased. This fact is supported from the following experiment. The dog being injected subcutaneously with $1 \%$ pilocarpine, the parotid saliva was collected from its duct, and the arterial as well as the venous blood was collected from the carotid artery and the external jugular vein respectively. Most of branches of the external jugular vein except that from parotid gland were tied off, and thus the venous blood originated mostly from the parotid gland. The outline of the experimental results is illustrated in fig. 4 . It is clearly demonstrated that the $p_{\mathrm{H}}$ of venous blood decreases while the salivary flow is accelerated. As the acceleration of salivary flow is accompanied with increase of $p \mathrm{H}$ as well as of total $\mathrm{CO}_{2}$ content in saliva, the bicarbonate excretion of saliva should be increased at this stage, and thus the blood $p_{\mathrm{H}}$ may be decreased by an increased formation of acid in tissue fluid.

As to the localization of carbonic anhydrase in gland tissues, Van Goor (4) suggested that the serous cell contains the enzyme, because the carbonic an- 

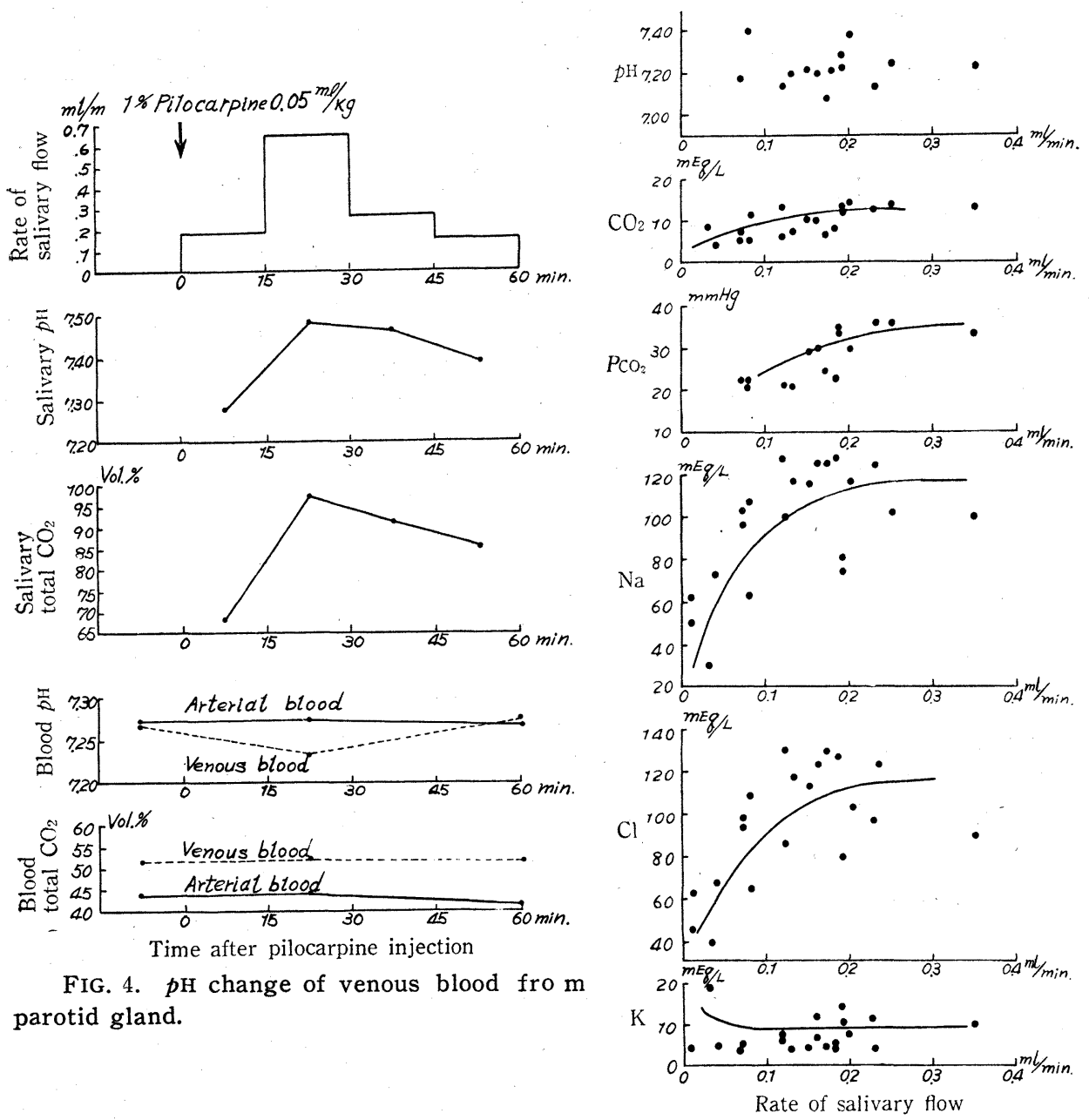

FIG. 5. Composition of rabbit parotid saliva in relation with rate of salivary flow.

hydrase content increases as the gland is composed of more serous cells. While it is true that the alveoli of parotid gland are composed entirely of the serous cells, and those of submaxillary and of sublingual glands are of the mixed type, the above suggestion is not necessarily the only one which is derived from the present results. Referring to the site of carbonic anhydrase, the authors wish to draw attention to the fact that the development of straited part of the gland duct is remarkable in the parotid as well as the submaxillary gland, while the sublingual gland has few. Therefore another suggestion is that the carbonic anhydrase is contained in the striated part.

To examine which suggestion is more plausible, the enzyme content of rabbit parotid gland was analysed by the method similar to that used in dogs, 
because its alveoli are composed mainly of serous cells while the striated part is not so well developed as in dog's parotid gland. As is seen in the last line of table 4, it is clearly demonstrated that the carbonic anhydrase content in the rabbit parotid gland is very little, though it is a little more than that in the sublingual gland of dogs. In fig. 5, the ionic concentration of rabbit parotid saliva are plotted against the rate of salivary flow. It is shown that the $p_{\mathrm{H}}$ and the total $\mathrm{CO}_{2}$ contents are very low as compared with parotid and submaxillary saliva of dog. Thus it is more plausible to presume that the carbonic anhydrase is contained in the striated part of the duct, and the bicarbonate excretion in saliva is performed by this part.

\section{General discussions on mechanisms of ionic excretion from salivary glands with special reference to their histological structures}

In order to discuss the excretion mechanism of ions from various sorts of salivary glands the excretory rates of ions per minute per g. of gland tissue are calculated by multiplying the ionic concentrations with the flowing rates per minute per $\mathrm{g}$. and are plotted in relation with the rate of salivary flow in fig. 6 and 7. Data are of four dogs of which the salivary glands were weighed for determination of carbonic anhydrase.

The excretion of ions from the parotid gland of dog will at first be discussed. As is seen in fig. 6, the excretory rate of $\mathrm{Na}^{+}$approximates a linear function of salivary flow above a certain limit of flowing rate, whereas that of $\mathrm{K}^{+}$is on a line passing the original point at all excretory rates. The regression line of the rate of $\mathrm{Na}^{+}$calculated by the method of least square has a slope of $0.113 \mu \mathrm{Eq} / \mu \mathrm{l}$., and an intercept of $-3.3 \mu \mathrm{Eq} / \mathrm{min} / \mathrm{g}$. on the ordinate axis. This value will be called as an intercept constant in this paper. If the hypothesis of Thaysen $e t$ al. may be adopted, the fact may be explained by a transfer of sodium into a preccusor solution of saliva at a rate of $0.113 \mu \mathrm{Eq} / \mu \mathrm{l}$. from which sodium is again reabsorbed at a rate of $3.3 \mu \mathrm{Eq}$. per minute per g. tissue.

A similar regression line is obtained for the excretion rate of sum of $\mathrm{Na}^{+}$ and $\mathrm{K}^{+}$and its slope is $0.114 \mu \mathrm{Eq} / \mu \mathrm{l}$., which is mainly determined by the rate of the most dominant $\mathrm{Na}^{+}$ions. The fact suggests that the precursor solution may be produced as a hypotonic solution, because it is verified by another experiment (unpublished) that the osmolar concentration in dog saliva is maintained mostly by $\mathrm{Na}$-and $\mathrm{K}$-salts and the cation concentration in isotonic saline is $0.16 \mu \mathrm{Eq} / \mu 1$. (see also Yoshimura et al. (1)). (The dotted line in fig. 6 is drawn to illustrate the slope of $0.16 \mu \mathrm{Eq} / \mu 1$.).

The excretion rates of anions in parotid saliva are illustrated in fig. 7. The excretion rate of $\mathrm{Cl}^{-}$as well as of $\mathrm{HCO}_{3}{ }^{-}$shows a linear regression in relation with the rate of salivary flow above a certain level restively, and the slopes of regression lines of both ions are approximately the same with each other. It is reasonable that the slope of excretory rate of total sum of $\mathrm{HCO}_{3}{ }^{-}$and $\mathrm{Cl}^{-}$ approximates that of total cations, because the anions in saliva are mainly composed of $\mathrm{HCO}_{3}^{-}$and $\mathrm{Cl}^{-}$.

With regard to the excretion rates of ions from submaxillary gland, similar results are obtained as are illustrated in fig. 6 , and fig. 7 . Since the slopes of 


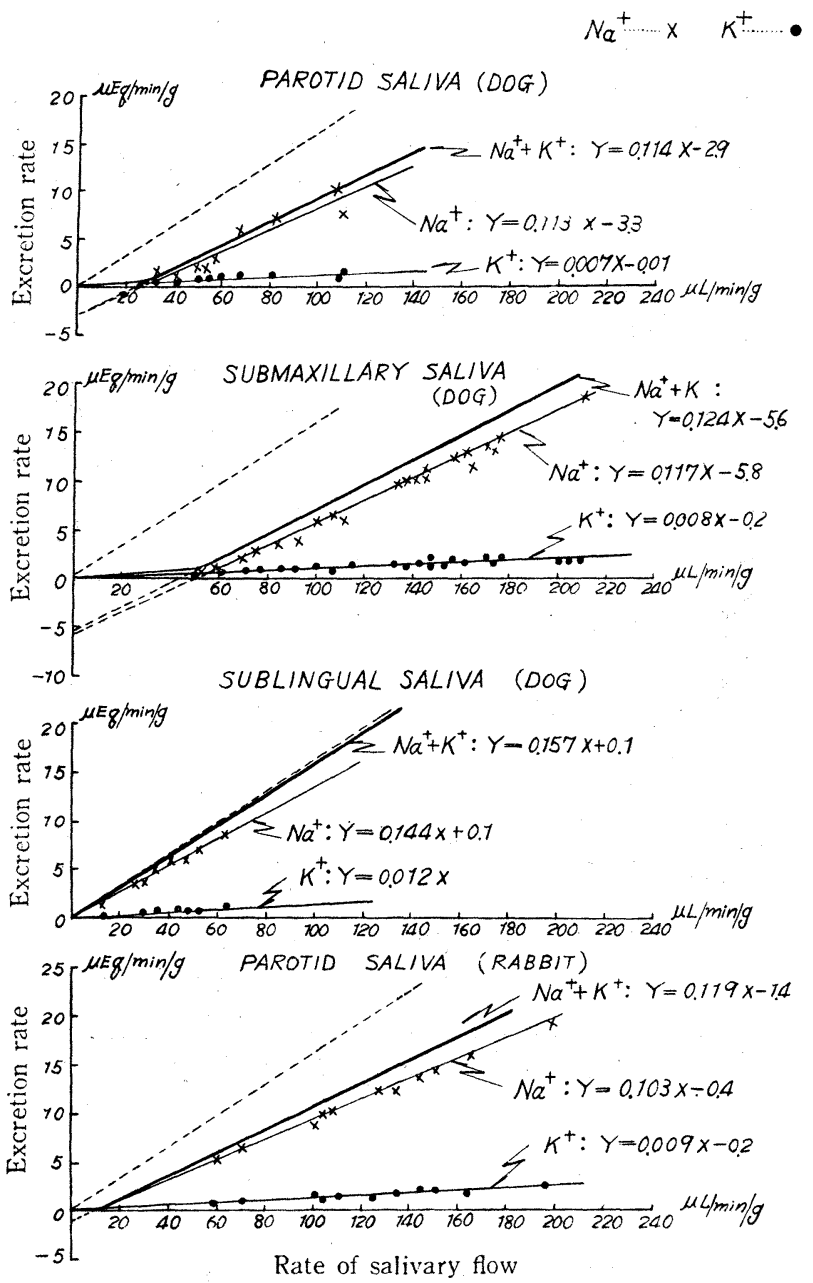

FIG. 6. Regression of cation excretion rate on salivary water excretion (dog and rabbit).

regression lines of total cations and of total anions are $0.124 \mu \mathrm{Eq} / \mu \mathrm{l}$. and 0.136 $\mu \mathrm{Eq} / \mu \mathrm{l}$. respectively, the precursor solution of submaxillary saliva may be produced as a hypotonic solution, and the fact that the intercept constants for all ions except $\mathrm{K}^{+}$are negative, may be explained by some reabsorptive process according to Thaysen et al. (8). The intercept constant for $\mathrm{K}^{+}$is approximately zero as is the case for parotid gland. A different point from the latter is that the excretion rate of $\mathrm{Cl}^{-}$is two times higher than that of $\mathrm{HCO}_{3}^{-}$in submaxillary saliva.

In the case of sublingual saliva, the regression lines of all ions pass near the original point. It means that the intercept constants of $\mathrm{Na}^{+}, \mathrm{K}^{+}, \mathrm{Cl}^{-}$and $\mathrm{HCO}_{3}{ }^{-}$are approximately zero, and no reabsorptive process may exist. As the 


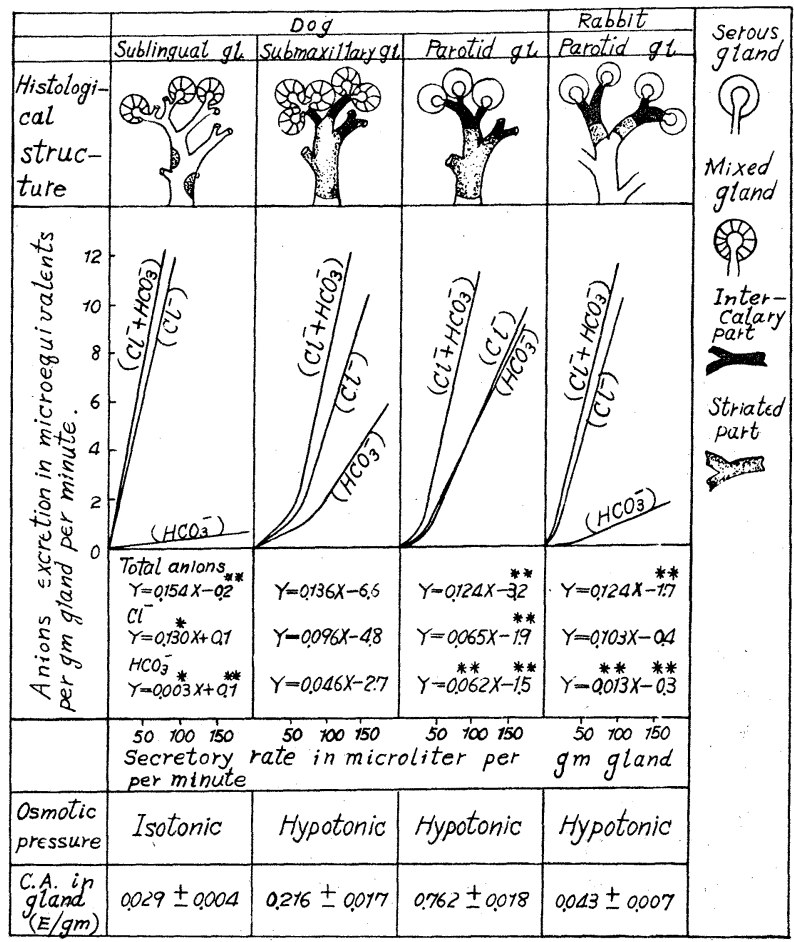

The values of submexillary saliva being taken as the standards, the constants of regression lines of ionic excretion rates are compared among various saliva. The value which is significantly different from the standard is marked with asterisk. * is at $5 \%$ level and ** at $1 \%$ level.

FIG. 7. Histological structures of salivary glands and ionic patterns of their saliva.

slope of the regression line of total cations is $0.157 \mu \mathrm{Eq} / \mu \mathrm{l}$. and that of total anions is $0.15 \mu \mathrm{Eq} / \mu \mathrm{l}$., the saliva produced is approximately isotonic at all excretory rate. The outstanding feature of ionic composition is a far lesser excretion of bicarbonate which was explained in relation with lacking of carbonic anhydrase in the sublingual gland (table 4).

The ionic excretion from parotid gland of rabbit resembles that from sublingual gland of dog. All the intercept constants of ions are very small, and the bicarbonate excretion is very little. A different point is, however, that the saliva is still hypotonic, as is indicated by a low regression coefficient of excretion rate of total cations or anions $(0.119 \mu \mathrm{Eq} / \mu \mathrm{l}$. for total cations and 0.124 $\mu \mathrm{Eq} / \mu \mathrm{l}$. for total anions). The fact indicates that the hypotonicity of saliva may not be effected solely by a reabsorptive process which is presumably represented by the negative intercept constant.

Now the excretion mechanism of ions from salivary gland will be discussed by criticizing the previous hypothesis. There seem to be many evidences that the saliva is produced by participation not only of alveoli but also of various 
parts in the duct. Opinions concerning the rôles played by these parts are, however, conflicting. According to recent hypothesis, the precursor solution is produced by alveoli and their vicinities, and a part of salt is apparently reabsorbed from this precursor solution. Thaysen $e t$ al. believed that the intercept constant of regression line of ionic excretory rate is an indication of the reabsorbed amount of salt. Therefore most of salts $\left(\mathrm{Na}^{+}, \mathrm{Cl}^{-}, \mathrm{HCO}_{3}^{-}\right)$in saliva seem to undergo such reabsorptive process when the saliva is hypotonic as is seen in fig. 6 and 7 . White et al. (9) suggested that this process is charged on the striated part of the duct, because they believed that excreta of those glands having the striated part in their excretory duct are all hypotonic.

In the present investigation, some evidences are given for this hypothesis as are illustrated in fig. 7, where the histological structures and the excretion rates of anions in various glands are compared. The histological structures are figured from descriptions in Babkin's book (7) as well as microscopic observations on preparations presented personally by Prof. Noda. It is shown that the magnitudes of the negative intercept constants of excretion rate of chloride as well as of bicarbonate from various glands run parallel with the developments of their striated parts. For example, the intercept constants for parotid as well as submaxillary gland of dog which has a well developed striated part are large, while those for sublingual gland having rudimentary rodded epithelium are very small. Rabbit parotid gland situates between these two extremities. A similar parallelism exists for the intercept constants of sodium excretion rate which are illustrated in fig. 6 . These facts strongly support the above hypothesis. An objection against this hypothesis is, however, that the bicarbonate is believed to be excreted from the striated part as was explained in the previous section. It seems unreasonable to postulate a reabsorptive process of bicarbonate in this same part where it undergoes the excretion. At the present, the authors have no definite evidence to decide the site of bicarbonate excretion as well as the reabsorptive process, and the future experiment is required.

Next, the mechanism of production of precursor solution in the gland will be discussed. As was pointed out already, the precursor solutions of parotid and submaxillary saliva of $\operatorname{dog}$ and of parotid saliva of rabbit are produced hypotonic, while dog's sublingual saliva is isotonic. Since the histological structure of sublingual gland is the simplest among all and has no intercalary epithelium and a poorly developed striated portion (fig. 7), it is reasonable to consider that the hypotonicity of precursor solution has an intimate bearing with the complicated structure of duct. It follows that the precursor solution secreted in alveoli of gland may be isotonic as is the case for sublingual gland. This assumption is supported by Lundberg's works $(18,19)$. After measuring the resting as well as the secretion potential of sublingual gland cell with micro-electrode, he presumed that the secretion of ions in alveoli of sublingual gland is mainly effected by active transport of $\mathrm{Cl}^{-}$, which is accompanied by passive transport of $\mathrm{Na}^{+}$and water (18). Thus he considered that the "primary secretion" in glands which secrete hypotonic saliva is iso- or hypertonic (19).

It is quite obscure at present why this precursor solution from alveoli is made hypotonic by passing through duct of parotid as well as of submaxillary 
gland. While the previous authors considered only a reabsorptive process of limited capacity played by the striated part as a possible mechanism $(8,9,19)$, the present experiments demonstrated the presence of another process which produces the hypotonic precursor before arriving at the limited reabsorption and of which the capacity may be indicated by a depression of regression coefficient of ion excretion rate. A possible suggestion for it given by histological structures is that a rôle may be played by the intercalary part of which the development seems to run parallel with the lowering of regression coefficients for total cations or anions. But there is no further evidence, and thus the problem of excretion of hypotonic saliva should be reinvestigated in future by taking together the reabsorptive process of the limited capacity into consideration.

Among the ions in saliva, differences of excretion rate of $\mathrm{Na}^{+}$among various glands can be explained as consequence of hypotonicity of saliva. It seems better to consider the excretion of $\mathrm{K}^{+}$differently from those of the other ions, because the regression coefficient is very small and almost the same among various glands and the intercept constant is always near zero. The mechanism of $\mathrm{K}^{+}$ excretion from salivary gland was fully discussed by Burgen (17).

Contrary to cations, the regression coefficients of $\mathrm{Cl}^{-}$and $\mathrm{HCO}_{3}{ }^{-}$excretions differ considerably among the glands. The difference may have an intimate relation with the development of striated part of the duct as was suggested already in connection with the bicarbonate excretion.

\section{SUMMARY}

Experimental studies are made to clarify the rôle of carbonic anhydrase upon the bicarbonate excretion from salivary glands with special reference to excretory mechanism of ions. Animals are mainly dogs and partly rabbits which are administrated with pilocarpine to promote salivary excretion. Outline of results are as follows;

1) The bicarbonate excretion from parotid gland is depressed by administration of various carbonic anhydrase inhibitors, and the salivary $p_{\mathrm{H}}$ is decreased while $\mathrm{CO}_{2}$ partial pressure in saliva is increased. Among the inhibitors examined, Diamox is the most powerful, then comes thiophen-2-sulfonamide, and next are $\mathrm{Na}_{2} \mathrm{~S}, \mathrm{NaN}_{3}$, sulfanilamide and $p$-sulfonamide benzoic acid, while NaSCN exerts the minimum action. This order of inhibitory actions coincides with that of inhibitory effects upon blood carbonic anhydrase which was determined by the in vivo experiment.

2) The bicarbonate excretion in saliva differs among various salivary glands. Its excretion rates relative to rate of salivary flow from the gland examined are in the following order: parotid gland of $\operatorname{dog}>$ submaxillary gland of $d o g>$ parotid gland of rabbit $>$ sublingual gland of dog. This order coincides with that of carbonic anhydrase contents in theses glands.

From these, it is concluded that the bicarbonate in saliva is produced in gland cells from metabolic $\mathrm{CO}_{2}$ under the action of carbonic anhydrase.

By comparing the relative amount of carbonic anhydrase in these glands 
with their histological structures, the site of its production is suggested to be the striated part of gland duct.,

3) The concentrations of $\mathrm{Na}^{+}, \mathrm{Cl}^{-}$and $\mathrm{HCO}_{3}^{-}$in parotid saliva as well as in submaxillary saliva increase as the rate of salivary flow is accelerated, and approach certain maximum levels respectively. The $\mathrm{K}^{+}$concentration is maintained almost constant regardless of salivary flow except when the flowing rate is very low. The ionic concentrations in sublingual saliva of dog are all maintained approximately constant.

The total ionic concentrations in parotid and submaxillary saliva of dog and also in rabbit parotid saliva are hypotonic even at the maximum levels of concentrations, while that in sublingual saliva is approximately isotonic.

Among the ions in saliva, $\mathrm{Na}^{+}$and $\mathrm{Cl}^{-}$are the most dominating, $\mathrm{HCO}_{3}^{-}$is the next and $\mathrm{K}^{+}$and other ions are the least ones. Excretions of $\mathrm{Cl}^{-}$and $\mathrm{HCO}_{3}{ }^{-}$vary considerably among various glands, while that of $\mathrm{K}^{+}$does not differ so far. The concentration of $\mathrm{Na}^{+}$depends upon the tonicity of saliva.

4) The regression lines of excretory rates of main ions referring to the rate of salivary flow are estimated from these data, and, by comparing the constants of regression lines (the intercept constants and the regression coefficients) of various glands with their histological structures, the excretory mechanism of ions from salivary glands were discussed.

The authors wish to express their cordial thanks to Prof. Kimoto in Kyoto Pharmaceutical College for his kindness of synthesizing thiophensulfonamide, to Prof. H. Noda for his friendship to prepare histological preparations of salivary glands, and to American Cynamid Co. for sending Diamox. A part of expense of this research was defrayed from the grant of the Ministry of Education to whom the authors thanks are due.

\section{REFERENCES}

1. Yoshimura, H., TAkAOKA, W. AND MorI, T. Jap. J. Physiol. 4: 154, 1954.

2. SAND, H. F. J. Applied Physiol. 4: 66, 1951.

3. SAND, H. F. The Carbonic Acid Content of Saliva and Its Role in the Formation of Dental Calculus. Thesis. Oslo, Norway: University of Oslo, 1949.

4. VAN GOOR, H. Enzymologia, 13: 75, 1948.

5. DAvenport, H. W. Physiol. Rev. 26: 560, 1946.

6. Janowitz, H. D., Colcher, H., AND Hollander, F. Nature, 170: 499, 1952; Trans. New York Acad. Sci., Series II, 15: 54, 1952.

7. BABKIN, B. D. Secretory Mechanism of the Digestive Glands. P. B. Hoeber, Inc. New York (1950).

8. Thaysen, J. H., Thorn, N. A. And Schwartz, I. L. Amer. J. Physiol. 178: 155, 1954.

9. White, A. G., Entmacher, P. S., Rubin, G. AND Leiter, L. J. Clin. Invest. 34: 246, 1955.

10. Altschule, M. D. AND Lewis, H. D. J. B. C. 180: 557, 1949.

11. Yoshimura, H. J. Biochem. 23: 335, 1935.

12. SAITO, K. J. Biochem. 25: 79, 89, 1937.

13. MAtSudA, K. et al. Med. and Biol. 11: 303, 309, 1947.

14. Berliner, R. W., Kennedy, J. J. Jr. And Orloff, J. Amer. J. Med. 11: 274, 1951.

15. LANGE, B. Kolorimetrische Analyse, Weinheim: Verlag Chemie, Gmbh. 1952.

16. Schales, O. AND Schales, S. S. J. B. C. 140: 879, 1941.

17. Burgen, A. S. V. J. Physiol. 132: 20, 1956.

18. Lundberg, A. Acta Physiol. Scand. 40: 21, 35, 102, 1957.

19. Lundberg, A. Physiol. Rev. 38: 21, 1958. 